\title{
ON THE CUTTING EDGE OF HISTORICAL RESEARCH
}

Methods developed in African history are just beginning to be used by historians of other world areas.

Those methods-including linguistics, oral traditions, textual evaluation, comparative historical and historiographical research-are the major concern of African historians and of historians everywhere.

HISTORY IN AFRICA is an essential companion to any contemporary historical bookshelf.

$\$ 20$ per volume, plus postage and handling.

HISTORY IN AFRICA: A JOURNAL OF METHOD Professor David Henige, Editor

An annual publication of the African Studies Association, 255 Kinsey Hall, UCLA, 405 Hilgard Avenue, Los Angeles, CA 90024, (213) 206-8011. 


\section{INIBW IPITLR IPROM CROBSROADS PRBSB8}

Canoingity and Chacte in Sonctere Africa. By Gwendolyn M. Carter. 1986. 117 pp. Softcover. \$9.95. ISBN: 0-918456-57-6.

This new work by Gwendolyn Carter provides a highly readable account of the complexity of the politics in Southern Africa. Prof. Carter's personal experience and study of Africa has covered nearly four decades and has provided her with the opportunity "to learn at first hand something of the forces at wort in...that period, and to discoss them with a wide and varied range of persons imtimately involved in them. "The six essays provide a broad overview of the history and politics central to an understanding of the problems that face Southern Africa today. From the foreword by R. Hum Davis, Director of the Center for African Studies, Univ. of Florida:

The African challenge to coercive rule...emerges not only as a crucial issue for South Africans but also for the United States, the SADCC countries, and the world as a whole. To understand why this challenge has reached its current level of intensity, what direction events are likely to take in the months and years ahead, how the United States and other countries should respond to the trend of events, and what the long-range implications are, one has to get behind the headlines, the television coverage, and the statements of politicians and diplomats. For this, there is no better starting point than the published books and articles of Gwendolyn M. Carter."

Crossroads Press and the University of Florida Center for African Studies is pleased to make available this timely and significant contribution to the stody of Southern Africa at a most crucial juncture in the affairs of that region.

To obtain copies of Concinzity and Clesce please send \$9.95 to Crossroads Press, 255 Kinsey Hall, UCLA. Los Angeles, CA 90024. Make check/money order in U.S. \$ payable to "Crossroads Press". Include 10\% for postage and handling on domestic orders; $20 \%$ for foreign orders. Pre-payment only.

Name

Address

City State Zip

Amount enclosed (include postage \& handling) 
285 KINSEY HALL, UCIA

LOS, ANOELES, CA 90024

(213) 206-0011

\section{NIRW TIITIBIS}

ASEW: Iran Avars ar the Fon Feople of Benin. By Edna G. Bay. 1985. 48 pp. + 61 photographs. Softcover: \$10.00.

"An asen is a calabash on which one offers food to the dead." "An asen is momument to a dead person, a place where his spirit may rest." "An asen is an iron object to which you invite the presence of the spirit of a dead person." "Asen represent our desire to venerate our fathers, our mothers, our influemial elders, our ancestars."

The African Studies Association. Crossroads Press and the Emory University Museum of Art and Archealogy take great pleasure in announcing the availability of this catalogue from the excibition "ASEN: IRON ALTARS OF THEFON PEOPLE OF BENIN", beld October 2-December 21, 1985 at Emory University. Conceived by Dr. Edn: Bay of the Emory University Graduate Institute of Liberal Arts, the exhibition presented 39 sculptures from the Abomey region of Benin. Rich with symbalism, asen, the ceremonial sculptures by which the Fon people honer their ancestors, represemt a blend of master craftmanship and dynamic artistic expression. The accompanying catalogue focuses on the making, meaning, ose and history of asen among the Fon people.

Crossroads Press, in conjunction with the Emory Museum of Art and Archeology, makes this valuable contribution to the field of African an history available for the special sale price of $\$ 6.00$. Prepayment only! For domestic onders include $10 \%$ for postage and handling; for foreign orders include $20 \%$. Make chect/money order in U.S. $\$$ paymble to Crossroads Press. Mail to Africun Studies Association, 255 Kinsey Hall, UCLA, Los Angeles, CA 90024 .

Please send:

copy/copies of ASkaN- Iron Alters or whe Fou Prople or Becie @ $\$ 6.00$

Name

Address

City State Zip

Amount enclosed (include pastage and handling) \$

$6 / 2$ 


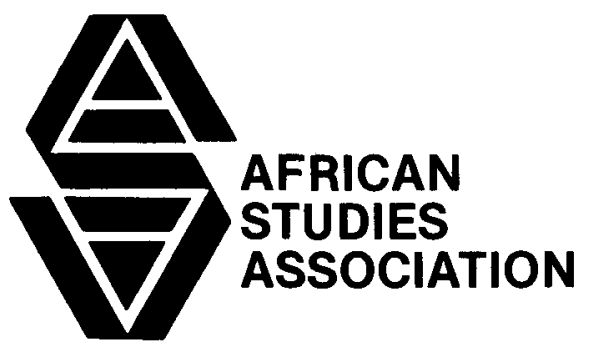

ISSN: 0278-2219

ASA News, Vol. XIX, No. 2, April/June, 1986. Editors: John Distefano and Eric D. Wright. Published quarterly by the African Studies Association. Contributions should be sent to $A S A$ News, Kinsey Hall, UCLA, Los Angeles, CA 90024. All $A S A$ individual and institutional members receive ASA News, Issue and the African Studies Review. Domestic claims for non-receipt of issues must be made within six months of the month of publication - overseas claims must be made within one year.

Notice to Members: The United States Postal System does not always forward periodicals. We must receive written notification from you at least five weeks in advance of any change of address. Failure to notify us of your correct mailing address will result in suspension of your membership until we receive such notification. We can make address changes only when current dues are paid. Reinstatement of membership after suspension may be made by payment of a $\$ 5.00$ reinstatement fee.

University of California, Los Angeles AFRICAN STUDIES ASSOCIATION 255 Kinsey Hall

Los Angeles, California 90024

Non-Profit

ORG

U.S. Postage

PAID

UCLA 